\title{
Effect of Treated Filter Cake on Yield and its Components of Sugar Beet under Saline Soil Condition
}

\author{
Mohsen A. Gameh', Ramadan E. Knany', Yahya U. Drwesh', \\ Fekry M. Ismaeil $^{3}$, Salah F. Abou-Elwafa ${ }^{4,5}$, \\ ${ }^{1}$ Department of Soils and Water, Faculty of Agriculture, Assiut \\ University, Egypt. \\ ${ }^{2}$ Soils, water and Environment Research. Institute. Agricultural \\ Research Center, Giza, Egypt. \\ ${ }^{3}$ Delta Sugar Company, El-Hamool, Kafr El-Sheikh, Egypt. \\ ${ }^{4}$ Faculty of Sugar and Integrated Industries Technology, Assiut \\ University, Egypt. \\ ${ }^{5}$ Agronomy Department, Faculty of Agriculture, Assiut University, \\ Egypt.
}

\begin{abstract}
Sugar beet, the first sugar crop in Egypt, is one of the most salt tolerant crops. Tremendous amounts of sugar beet industrial byproducts, including filter cake, are annually produced from beet sugar factories causing environmental problems. A field experiment was conducted at the Research Farm of Delta Sugar Company, Kafr El-Sheikh during the two successive seasons of 2017/2018 and 2018/2019 aiming to the response of sugar beet to application of sulphuric and phosphoric acids-treated filter cake under saline soil condition in terms of growth, yield and quality.

Application of 1 ton/fed. of treated filter cake significantly enhanced root length, diameter and leaf area in both growing seasons. The highest values of root length and diameter, leaf area, root and top yields were obtained from the application of either 1 or 2 tons/fed. of treated filter cake. Molasses application led to significant enhancement of root length and diameter and leaf area as well. Application of molasses at the rate of $50 \mathrm{~L} / \mathrm{fed}$. significantly increased root and top yields.
\end{abstract}

Keywords: Sugar beet; Soil amendments; Filter cake; Molasses; Soil salinity. 


\section{Introduction}

Sugar beet (Beta vulgaris L) is the is ranked as the first sugar crop in Egypt (www.fao.org). The importance of the crop comes not only from its ability to grow in the newly reclaimed soils, but from its ability to produce a higher sugar content in short growing season. Water scarcity, steady population growth and decreasing sugarcane harvested area necessitate the expansion in sugar beet cultivation to overcome the gap between sugar production and consumption in Egypt (Abo-Elwafa et al. 2006; Abou-Elwafa 2010; Abo-Elwafa et al. 2013). Sugar beet is one of the most salt tolerant crops, however it is less tolerant during seed germination and seedling establishment. Increasing of EC level above $6 \mathrm{dSm}^{-1}$ drastically reduces seedling emergence rate and dry weight (Kaffka and Kurt 2004). In addition, increasing soil salinity level significantly reduces germination \%, germination rate, seedling length, seedling fresh weight and seedling vigor of all sugar beet varieties under investigation to different extents (Abd El-Hady et al. 2014). Furthermore, soil salinity resulted in osmotic and oxidative stress, ion toxicity, nutritional imbalances, decreasing cell division and changes in metabolic processes such as photosynthesis, respiration, and disruption of plant membranes disorganization of (Hasanuzzaman et al. 2014).

In Egypt, tremendous amount of sugar beet industrial byproducts are produced from beet sugar factories. These industrial byproducts are increasing annually causing environmental pollution. Filter cake, a byproduct of using the lime stones in juice clarification, is an important byproduct which contains organic matter and have relatively high CEC values. Thus, a beneficial utilization of the large quantity of lime wastes (filter cake) produced annually is a great challenge (Ippolito et al. 2013). Superphosphate (Delta Superphosphate) was produced from filter cake, which is mainly composed of calcium carbonate, when it was mixed with a 1:1 diluted phosphoric acid after using different portions and mixing for a definite time, and sulphuric acid (98\%) in different proportions for a definite time (Abd El-Samea 2009). Beside, some chemical 
properties of the soil was greatly improved when a mixture of byproducts including filter cake treated with commercial $\mathrm{H}_{2} \mathrm{SO}_{4}$ was applied (Amer 2015). Application of phosphogypsum (PG) which has been traditionally applied as Ca-amendment in saline soils increased sugar beet yield (Rymar' et al. 2003; Abril et al. 2009).

Humic acid, which is major components of soil organic matter, have multiple roles in plant growth and in various areas of agriculture, such as soil chemistry, soil fertility and plant physiology (Ouni et al. 2014). Foliar application of Humic acid at rates of 15, 20 and 25 g/ L significantly improved sugar beet growth parameters, i.e., root length, diameter and size, number of leaves, root and leaves fresh weight, root and leaves dry weight and root yield (EL-Gamal et al. 2016). Furthermore, soil physical and chemical properties and nutrient dynamics were substantially improved in response to application of the natural material Potassium humate (K-humate) (Abd-All et al. 2017). Application of sugar beet molasses mitigates the negative effects of salinity on tomato growth (El-Tokhy et al. 2019).

The objective of the present study is to investigate effect of filter cake treated with sulphoric and phosphoric acids and some other amendments on growth and yield of sugar beet.

\section{Material and methods}

\subsection{Plant material and evaluation}

A field experiment was conducted at the Delta Sugar Company Research Farm, El-Hamool, Kafr El- Sheikh, Egypt during the two successive growing seasons of 2017/2018 and 2018/2019. The sugar beet cultivars Top and Bleno was grown in the first and second growing seasons, respectively. 
Table 1: Basic physical and chemical properties of experimental soil.

\begin{tabular}{|c|c|c|}
\hline Parameters & $2017 / 2018$ & $2018 / 2019$ \\
\hline Silt \% & 23.6 & 24.7 \\
\hline Sand \% & 29.1 & 28.3 \\
\hline Clay \% & 47.3 & 47.0 \\
\hline Texture grade & Clayey loam & Clayey loam \\
\hline $\mathrm{CaCO}_{3} \%$ & 3.8 & 4.7 \\
\hline pH & 7.97 & 8.20 \\
\hline EC dSm-1 & 8.67 & 7.50 \\
\hline \multicolumn{3}{|c|}{ Soluble cations, meq $\mathrm{L}^{-1}$} \\
\hline $\mathrm{Ca}^{2+}$ & 32.70 & 26.22 \\
\hline $\mathrm{Mg}^{2+}$ & 20.35 & 20,75 \\
\hline $\mathrm{Na}^{+}$ & 32,32 & 27.26 \\
\hline $\mathbf{K}^{+}$ & 1.40 & 1.54 \\
\hline \multicolumn{3}{|c|}{ Soluble anions, meq $\mathrm{L}^{-1}$} \\
\hline $\mathrm{Cl}^{-}$ & 52.00 & 42.55 \\
\hline $\mathrm{HCO}_{3}^{-}$ & 4.00 & 5.16 \\
\hline $\mathrm{SO}_{4}{ }^{2-}$ & 30.78 & 28.06 \\
\hline \multicolumn{3}{|c|}{ Available nutrients ppm } \\
\hline $\mathbf{N}$ & 30 & 28 \\
\hline $\mathbf{P}$ & 7.5 & 7.6 \\
\hline $\mathbf{K}$ & 366.6 & 460 \\
\hline
\end{tabular}

Plants were grown on October 22, 2017 and 2018 and harvested on May 15, 2018 and 2019 in the first and second growing seasons, respectively. Seeds were hand sown at $15-20 \mathrm{~cm}$ spaces in a $15 \mathrm{~m}^{2}$ plot consists of 5 rows of $5 \mathrm{~m}$ length, with a distance of $60 \mathrm{~cm}$ between rows. Recommended doses of N, P and $\mathrm{K}$ and all other cultural practices were performed according to locally recommended practices for sugar beet production. The main soil properties $(0-20 \mathrm{~cm}$ depth) are described in Table 1 . Analysis of the physical and chemical properties of the soil was performed according to Bao (2005). 
At harvest, root length and diameter $(\mathrm{cm})$, leaf area $\left(\mathrm{cm}^{2}\right)$, r' 5 yield (t/fed.) and shoot fresh weight (top yield; t/fed.) were d.... mined.

\subsection{Soil amendments and filter cake treatment}

Four soil amendments, i.e., Phosphogypsum (PG) which is a byproduct of the processing of phosphate rock in plants producing phosphate fertilizers such as superphosphate and phosphoric acid, Desal which is a desalination commercial product, Humic acid and treated filter cake. To convert the filter cake (lime cake) from deleterious material to useful material, the filter cake produced from Delta Sugar Company stored from the previous years was treated with a mixture of sulphoric and phosphoric acids (1.5:1) $(18+12$ $\mathrm{cm}^{3} / 100 \mathrm{~g}$ ). The final product contains a mixture of gypsum and monocalcium phosphate beside a portion of calcium carbonate. All four types of soil amendments were sprayed on the soil surface before sowing.

\subsection{Experimental design and statistical analysis}

Experiments arrangement were designed in a four-replicates randomized complete block design (RCBD) in a split plot design. The main plots were assigned to six soil amendment treatments, i.e., control treatment (without amendments), 1ton/fed. of treated filter cake, 2 tons/fed. of treated filter cake, 1 ton/fed. of phosphogypsum (PG), 4 1/fed. of Desal (desalinization), sprayed on the soil surface before sowing and 4 1/fed. of Humic acid sprayed on the soil surface before sowing. The sub-plots were assigned to three molasses treatments, i.e., control treatment (without molasses application), 25 $\mathrm{L} / \mathrm{fed}$. of molasses sprayed on the soil surface before sowing and 50 L/fed. of molasses sprayed on the soil surface before sowing. The Proc Mixed of SAS 130 package version 9.2 was used to perform analysis of variance (ANOVA), Fisher's least significant difference (LSD), of significantly differed treatments was calculated. 


\section{Results and discussion}

\subsection{Application of treated filter cake and molasses enhances sugar beet growth}

Application of 1 ton/fed. of treated filter cake significantly enhanced root length, diameter and leaf area in both growing seasons (Table 2). The highest values of root length in both growing seasons (26.48 and 25.68 in the first season and 25.29, and 25.14 in the second season) were obtained from the application of 1 and 2 tons/fed. of treated filter cake, respectively. No significant difference between the application of either 1 or 2 ton/fed. of treated filter cake was observed in root length. Likewise, the application of 1 and 2 ton/fed. of treated filter cake resulted in the highest root diameter in both growing season, however the differences between the application of either 1, 2 ton/fed. of treated filter cake, Desal $(12.02 \mathrm{~cm})$ or humic acid were insignificant (Table 2). The largest leaf area $\left(168.42 \mathrm{~cm}^{2}\right)$ was obtained from the application of 1 ton/fed. of treated filter cake in the first growing season. Meanwhile, in the second growing season the highest leaf area $\left(238.75 \mathrm{~cm}^{2}\right)$ resulted from the application of Desal, however it was not significantly different from that resulted from the application of 1 ton/fed. of treated filter cake (Table 2). The action of treated filter cake in enhancing root length, diameter and leaf area could be attributed to its high calcium content that dramatically improves soil properties and hence enhances sugar beet growth. The difference pattern observed in the leaf area between the two growing seasons could due to the cultivation of a different cultivars. The application of $25 \mathrm{~L}$ of molasses/fed. resulted in the highest root diameter in the first season, while in the second season the application of molasses at $50 \mathrm{~L} / \mathrm{fed}$. produced the highest leaf area without significant difference between either application rates.

The interaction between soil amendments and molasses exhibited significant effects on root length, diameter and leaf area in 
the first growing season, while in the second growing season the si 7 ficant effects were only observed on leaf area (Table 2). The highest root length and leaf area values in the first growing season $\left(27.50 \mathrm{~cm}\right.$ and $\left.181.75 \mathrm{~cm}^{2}\right)$ were obtained from the application of 1 ton/fed of treated filter cake and 25L molasses/fed. Meanwhile, the application of Desal in combination with either $25 \mathrm{~L}$ or $50 \mathrm{~L}$ of molasses per feddan resulted in the highest root diameter in the first reason $(12.65 \mathrm{~cm})$, and leaf area in the second season (248.75).

\subsection{Soil amendments improve root and top yields}

Soil amendments revealed highly significant effects on root, top yields and sugar content. The highest root yields (26.11 and 29.43 tons/fed.) in the first and second growing seasons, respectively, were obtained from the application of 1 ton/fed of treated filter cake. The highest top yield (7.66 and 15.75 tons/fed.) were obtained from the application of Desal in the first growing season and 1 ton/fed of treated filter cake in the second growing season (Table 3 ). 
Table 2: Effect of soil amendments and molasses application on root length and diameter as well as leaf area in the two growing seasons $2017 / 2018$ and 2018/2019.

\begin{tabular}{|c|c|c|c|c|c|c|c|}
\hline Soil amendments & Molasses & $\begin{array}{l}\text { Root Length } \\
\text { (cm) }\end{array}$ & $\begin{array}{l}\text { Root diameter } \\
(\mathbf{c m})\end{array}$ & $\begin{array}{l}\text { Leaf area } \\
\qquad\left(\mathrm{cm}^{2}\right)\end{array}$ & $\begin{array}{l}\text { Root Length } \\
\text { (cm) }\end{array}$ & $\begin{array}{l}\text { Root diameter } \\
(\mathbf{c m})\end{array}$ & $\begin{array}{l}\text { Leaf area } \\
\left(\mathrm{cm}^{2}\right)\end{array}$ \\
\hline \multirow[t]{3}{*}{ Control } & Control & $18.45 \mathrm{~d}$ & $9.27 \mathrm{e}$ & 124.00 de & 22.77 & 12.92 & $139.50 \mathrm{f}$ \\
\hline & 25L Molasses & $20.32 \mathrm{~cd}$ & 10.33 cde & 157.75 abc & 23.67 & 13.30 & 159.50 ef \\
\hline & 50L Molasses & $20.22 \mathrm{~cd}$ & 9.95 de & 146.50be & 23.80 & 13.70 & 168.00 def \\
\hline \multicolumn{2}{|c|}{ Mean } & $19.66 \mathrm{c}$ & $9.85 b$ & $140.88 c$ & 23.41b & 13.31b & $155.67 d$ \\
\hline \multirow{3}{*}{$\begin{array}{l}\text { Filter cake } \\
\text { (1 t/fed.) }\end{array}$} & Control & $27.25 \mathrm{a}$ & $12.02 \mathrm{ab}$ & $172.75 \mathrm{ab}$ & 25.38 & 15.20 & $235.50 \mathrm{ab}$ \\
\hline & 25L Molasses & $27.50 \mathrm{a}$ & $11.97 \mathrm{ab}$ & 181.75 a & 25.20 & 14.72 & 224.00 abc \\
\hline & 50L Molasses & $24.68 \mathrm{~b}$ & $11.92 \mathrm{ab}$ & 150.75 bcd & 25.30 & 14.47 & 233.00 abc \\
\hline \multicolumn{2}{|c|}{ Mean } & 26.48 & $11.97 a$ & $168.42 a$ & $25.29 \mathrm{a}$ & $14.80 \mathrm{a}$ & 230.83a \\
\hline \multirow{3}{*}{$\begin{array}{l}\text { Filter cake } \\
\text { ( } 2 \text { t/fed.) }\end{array}$} & Control & $27.00 \mathrm{a}$ & $12.60 \mathrm{ab}$ & $173.75 \mathrm{ab}$ & 24.90 & 13.77 & $198.50 \mathrm{~cd}$ \\
\hline & 25L Molasses & 24.77 b & $11.95 \mathrm{ab}$ & $156.25 \mathrm{abc}$ & 25.15 & 14.32 & $205.00 \mathrm{bc}$ \\
\hline & 50L Molasses & $25.27 \mathrm{~b}$ & $12.20 \mathrm{ab}$ & 158.25 abc & 25.37 & 14.65 & 209.00 bc \\
\hline \multicolumn{2}{|c|}{ Mean } & $25.68 a$ & $12.25 \mathrm{a}$ & $162.75 a$ & $25.14 a$ & $14.25 \mathrm{~b}$ & 204.17b \\
\hline \multirow[t]{3}{*}{ Phosphogypsum } & Control & $21.12 \mathrm{c}$ & 10.00 de & 139.50cde & 23.80 & 13.25 & 166.75 def \\
\hline & 25L Molasses & $18.57 \mathrm{~d}$ & 9.77 de & $120.25 \mathrm{e}$ & 24.57 & 13.47 & 232.25 abc \\
\hline & 50L Molasses & $21.08 \mathrm{c}$ & 9.90 de & 141.75 cde & 24.67 & 14.05 & 238.50 ab \\
\hline \multicolumn{2}{|c|}{ Mean } & $20.26 c$ & $9.89 \mathrm{~b}$ & 133.83d & 24.35ab & $13.59 \mathrm{~b}$ & $212.50 b$ \\
\hline \multirow[t]{3}{*}{ Desal } & Control & $21.10 \mathrm{c}$ & $11.20 \mathrm{bc}$ & $140.00 \mathrm{cde}$ & 24.85 & 14.07 & $239.25 \mathrm{ab}$ \\
\hline & 25L Molasses & $23.82 \mathrm{~b}$ & $12.65 \mathrm{a}$ & 156.50 abc & 24.92 & 14.10 & 228.25 abc \\
\hline & 50L Molasses & $24.00 \mathrm{~b}$ & $12.20 \mathrm{ab}$ & 153.25 abc & 25.12 & 14.32 & 248.75 a \\
\hline \multicolumn{2}{|c|}{ Mean } & 22.97b & $12.02 a$ & $149.92 b c$ & 24.96a & 14.16ab & 238.75a \\
\hline \multirow[t]{3}{*}{ Humic acid } & Control & $21.15 \mathrm{c}$ & $10.70 \mathrm{~cd}$ & 142.00 cde & 23.80 & 13.30 & 166.75 \\
\hline & 25L Molasses & $21.90 \mathrm{c}$ & $12.57 \mathrm{ab}$ & 152.75 abc & 23.87 & 13.35 & 171.75 def \\
\hline & 50L Molasses & $24.65 \mathrm{~b}$ & $12.35 \mathrm{ab}$ & 163.25 abc & 24.65 & 13.90 & $175.75 \mathrm{de}$ \\
\hline \multicolumn{2}{|c|}{ Mean } & $22.57 b$ & $11.87 a$ & 152.67b & 24.11ab & $13.52 \mathrm{c}$ & 171.42b \\
\hline
\end{tabular}


The highest sugar contents (19.91 and 19.38\%) in the first and second growing seasons, respectively, resulted from the control treatment. This may be due to the presence of high calcium content ions in the treated filter cake which is antagonized with sodium ions and enhance soil aggregation which improves soil properties, plant growth and yield. Sugar percentage was decreased as increasing root yield by the dilution effect (Mohamedin et al 2012; Shaheen et al. 2017).

Table 3: Effect of soil amendments and molasses application on root and top yields in the two growing seasons 2017/2018 and 2018/2019.

\begin{tabular}{|c|c|c|c|c|c|}
\hline \multicolumn{2}{|c|}{ Growing season } & \multicolumn{2}{|c|}{$2017 / 2018$} & \multicolumn{2}{|c|}{$2018 / 2019$} \\
\hline $\begin{array}{c}\text { Soil } \\
\text { amendments }\end{array}$ & Molasses & $\begin{array}{c}\text { Root Yield } \\
\text { (t/fed.) }\end{array}$ & $\begin{array}{c}\text { Top } \\
\text { yield } \\
\text { (t/fed.) }\end{array}$ & $\begin{array}{c}\text { Root } \\
\text { Yield } \\
\text { (t/fed.) }\end{array}$ & $\begin{array}{c}\text { Top } \\
\text { yield } \\
\text { (t/fed.) }\end{array}$ \\
\hline \multirow[t]{3}{*}{ Control } & Control & $18.13 \mathrm{gh}$ & $4.16 \mathrm{de}$ & $21.70 \mathrm{~g}$ & 8.18 i \\
\hline & 25L Molasses & 20.30 efg & $4.25 \mathrm{de}$ & $23.05 \mathrm{f}$ & 9.48 ghi \\
\hline & 50L Molasses & 19.39 fgh & $4.57 \mathrm{~d}$ & 23.83 ef & $9.95 \mathrm{gh}$ \\
\hline \multicolumn{2}{|c|}{ Mean } & $19.27 \mathrm{e}$ & 4.33d & 22.86d & $9.20 \mathrm{e}$ \\
\hline \multirow{3}{*}{$\begin{array}{l}\text { Filter cake } \\
\text { (1 t/fed.) }\end{array}$} & Control & 26.03 a & 5.02 & 31.05 a & $16.50 \mathrm{a}$ \\
\hline & 25L Molasses & 27.20 a & $4.79 \mathrm{~d}$ & $28.40 \mathrm{bc}$ & $16.35 \mathrm{a}$ \\
\hline & 50L Molasses & $25.10 \mathrm{ab}$ & $4.17 \mathrm{de}$ & $28.85 \mathrm{~b}$ & $14.40 \mathrm{~b}$ \\
\hline \multicolumn{2}{|c|}{ Mean } & 26.11a & $4.66 d$ & $29.43 a$ & $15.75 a$ \\
\hline \multirow{3}{*}{$\begin{array}{l}\text { Filter cake } \\
\text { ( } 2 \text { t/fed.) }\end{array}$} & Control & $25.92 \mathrm{ab}$ & $7.01 \mathrm{~b}$ & 26.25 & $12.15 \mathrm{de}$ \\
\hline & 25L Molasses & 24.87 abc & $5.72 \mathrm{c}$ & $26.95 \mathrm{~cd}$ & $11.85 \mathrm{de}$ \\
\hline & 50L Molasses & $25.22 \mathrm{ab}$ & $4.79 \mathrm{~d}$ & 28.43 bc & $12.30 \mathrm{de}$ \\
\hline \multicolumn{2}{|c|}{ Mean } & $25.34 b$ & $5.84 \mathrm{c}$ & 27.21b & $12.10 \mathrm{c}$ \\
\hline \multirow{3}{*}{$\begin{array}{l}\text { Phosphogypsu } \\
\text { m }\end{array}$} & Control & 20.90 ef & $6.89 \mathrm{~b}$ & 23.70 ef & 9.10 ghi \\
\hline & 25L Molasses & $17.28 \mathrm{~h}$ & $2.68 \mathrm{f}$ & $25.50 \mathrm{de}$ & $9.80 \mathrm{gh}$ \\
\hline & 50L Molasses & $19.39 \mathrm{fgh}$ & $3.50 \mathrm{e}$ & $26.10 d$ & 11.17 ef \\
\hline \multicolumn{2}{|c|}{ Mean } & $19.19 \mathrm{e}$ & 4.36d & $25.10 c$ & $10.02 d$ \\
\hline \multirow[t]{3}{*}{ Desal } & Control & $21.95 \mathrm{de}$ & $6.89 \mathrm{~b}$ & $26.75 \mathrm{~d}$ & $13.60 \mathrm{bc}$ \\
\hline & 25L Molasses & 23.35 bcd & $9.46 \mathrm{a}$ & 25.45 de & $12.45 \mathrm{de}$ \\
\hline & 50L Molasses & 23.35 bcd & $6.65 \mathrm{~b}$ & $26.85 \mathrm{~cd}$ & $13.05 \mathrm{~cd}$ \\
\hline \multicolumn{2}{|c|}{ Mean } & $22.88 d$ & $7.67 a$ & $26.35 b$ & $13.03 b$ \\
\hline \multirow[t]{3}{*}{ Humic acid } & Control & 22.48 cde & $6.73 \mathrm{~b}$ & 23.70 ef & 9.00 hi \\
\hline & 25L Molasses & 23.50 bcd & $6.34 \mathrm{~b}$ & 23.55 ef & 9.43ghi \\
\hline & 50L Molasses & 24.69abc & $7.22 \mathrm{~b}$ & $25.95 d$ & $10.50 \mathrm{fg}$ \\
\hline \multicolumn{2}{|c|}{ Mean } & $23.56 c$ & $6.76 \mathrm{~b}$ & 24.40d & $9.64 \mathrm{e}$ \\
\hline
\end{tabular}




\section{References}

Abd-All, A.H.; A.E. Elnamas and E.M. El-Nagger (2017). Effect of humic acid and foliar application of different potassium sources on yield, quality and water use efficiency of sweet potatoes grown under drip irrigation sandy soil. Alex. Sci. Exch. 38:543-553.

Abd El-Hady, M. A.; T.Y. Rizk; M.E. El-Bially and M.A. Farag (2014). Salt tolerance index of twenty-two sugar beet (beta vulgaris 1.) varieties at early stages of growth. Arab Univ. j. agric. Sci., 22(2).

Abd El-Samea, A.M. (2009). Recycling of some by-products of sugar beet factories and their use in improving soil properties. M.Sc thesis, Assuit University.

Abo-Elwafa, S.F., Abdel-Rahim, H.M., Abou-Salama, A.M., Teama, E.A. (2006). Sugar beet floral induction and fertility: Effect of vernalization and day-length extension. Sugar Tech, 8, 281-287.

Abo-Elwafa, S.F., Abdel-Rahim, H.M., Abou-Salama, A.M., Teama, E.A. (2013). Effect of root age and day-length extension on sugar beet floral induction and fertility. World Journal of Agricultural Research, 1(5), 90-95.

Abou-Elwafa, S. (2010). Novel Genetic Factors Affecting Bolting and Floral Transition Control in Beta vulgaris (Doctoral dissertation). Faculty of Agricultural and Nutritional Sciences, ChristianAlbrechts-University of Kiel.

Abril, J. M.; Garcia-Tenorio, R.; Perianez, R.; Enamorado, S. M.; Andreu, L.; and A. Delgado (2009). Occupational dosimetric assessment (inhalation pathway) from the application of phosphogypsum in agriculture in South West Spain. Journal of Environmental Radioactivity;100 (1):29-34.

Amer, M. M. (2015). Effect of gypsum, sugar factory lime and molasses on some soil proprieties and productivity of sugar beet (beta vulgaris 1.) grown on saline-sodic soils of Nile North Delta. J. Soil Sci. and Agric. Eng., Mansoura Univ., Vol. 6 (3),1-20.

Bao, S.D. (2005). Soil and Agricultural Chemistry Analysis. Agriculture Press, Beijing, China. 
EL-Gamal, I.S.; Abd El-Aal, M. M. M.; El-Desouky, S. A.; Khedr, Z.M. and Abo Shady, K. A (2016). Effect of some growth substances on growth, chemical Compositions and root yield productivity of sugar beet (Beta vulgaris L.) Plant. Middle East $J$. Agric.Res., 5(2):171-185.

11 Tokhy K.F., Tantawy A.S., El-Shinawy, M.Z. and Abou- el- Hadid (2019). Effect of sugar beet molasses and fe-EDHHA on tomato plants grown under saline water irrigation condition. Arab Univ. J Agric. Sci., Ain Shams Univ., Cairo, Egypt, 26(9D), 2297-2310.

Hasanuzzaman, M., Alam, M.M., Rahman, A., Nahar, K. and Fujita, M. (2014). Exogenous proline and glycinebetaine mediated upregulation of antioxidant defense and glyoxalase systems provides better protection against salt-induced oxidative stress in two rice (Oryza sativa L.) varieties. Biol. Med. Re. Int., 17.

Ippolito, J. A., Strawn, D.G. and Scheckel, K. G. (2013). Investigation of copper sorption by sugar beet processing lime waste. J. Environ. Qual. 42: 919-924.

Kaffka, S. and Kurt, H. (2004). The effects of saline soil, irrigation, and seed treatments on Sugar beet. J. Sugar Beet Res., 41(3):61-72.

Mohamedin, A.A.M.; Ismail, A.O.A. and Seyam, H. M.M. (2012). Use efficiency of soil amendments and saline water on improving properties and productivity of sodic soil. Egypt. J. of Appl. Sci., 27(1): 51-60.

Olsen, S.R and L.F Sommers (1982). Methods of Soil Analysis.Part 2, Chemical, microbiological properties. Agron. J. Amer. Soc. Agron. Madison Wiss., USA.PP 403-430.

Ouni, Y., T. Ghnaya, F. Montemurro, Ch. Abdelly, and A. Lakhdar (2014). The role of humic substances in mitigating the harmful effects of soil salinity and improve plant productivity. International Journal of Plant Production 8 (3), 1735-8043.

Rymar,V.T.; Mukhina, S.V.; Agafonov, D.N.; Skrebnev, V.N. and V.V Avdeeva (2003). Effect of fertilization on yield and quality of barley. Kormoproizvodstvo; 2003. (10):14-16.

Shaheen, S. M.; Shams, M. S.; Khalifa, M. R.; El-Dali, M. A. and J, Rinklebe (2017). Various soil amendments and environmental wastes affect the (im) mobilization and phytoavailability of 
Mohsen A. Gameh et al. (2020), Egyptian Sugar Journal, Vol.15

potentially toxic elements in a sewage effluent irrigated sandy soil. Ecotoxicology and Environmental Safety; 142:375-387. 


\section{الملخص العربي}

تأثير إضافة الطينة الصفر اء المعالجة على محصول بنجر السكر ومكوناته تحت ظروف الار اضى الملحية ماءلية

محسن عبد المنعم جامع1، رمضان إسماعيل كناني، يحيي يوسف إبر اهيم درويش³، فكري محمد علي

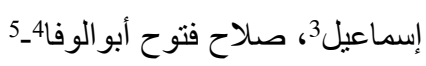

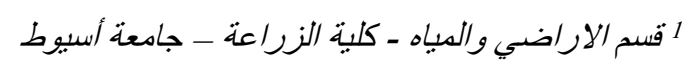

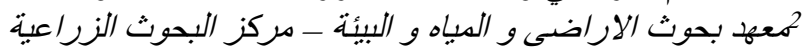

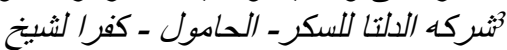

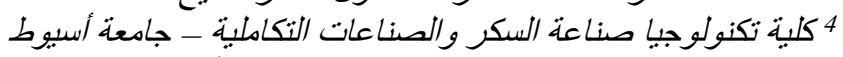
5 قنسم المحاصيل - كلبة الزراعة - جامعة أسيوط

1) أجريت تجربة حقلية بالمزرعة البحثية لشركة الالتا للسكر، مصنع الحامول -

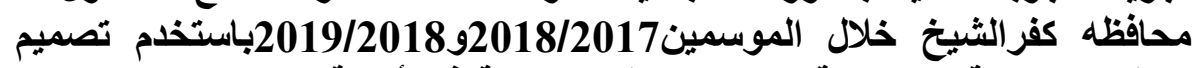

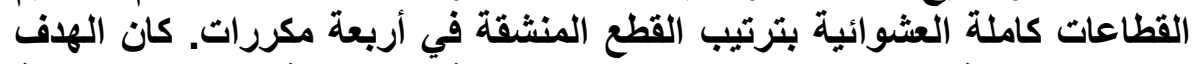

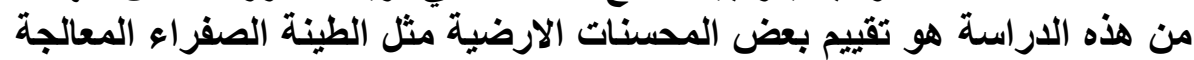

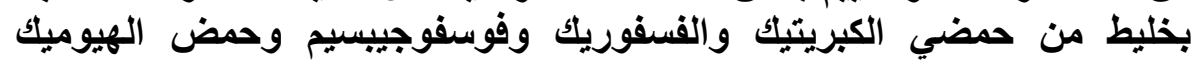

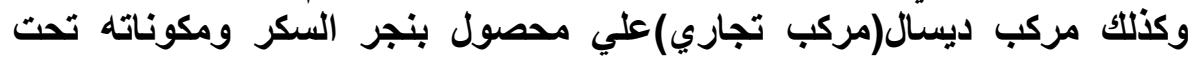

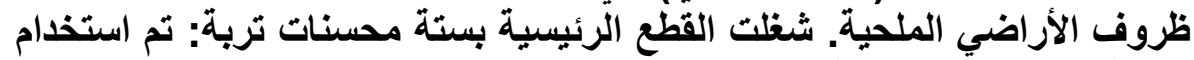

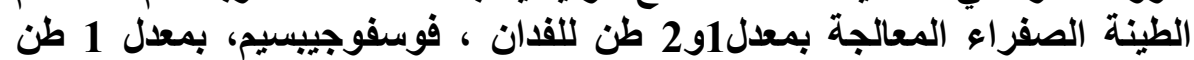

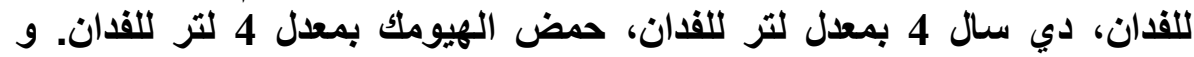

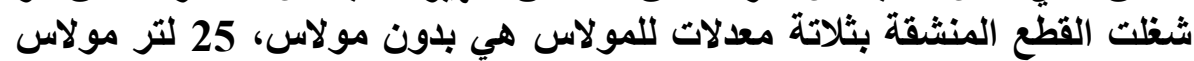
للفدان، 50 لتر مولاس للفدان.

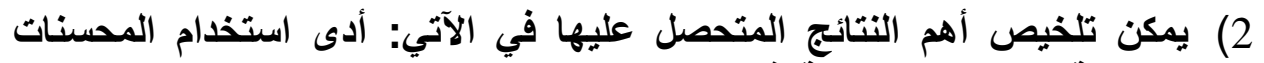

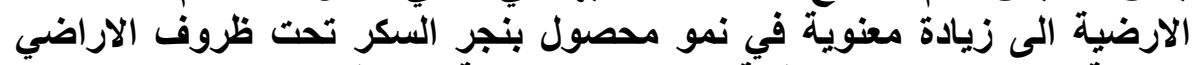

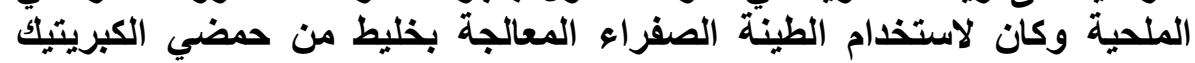

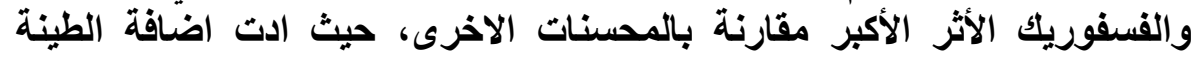

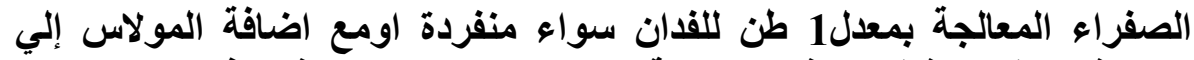

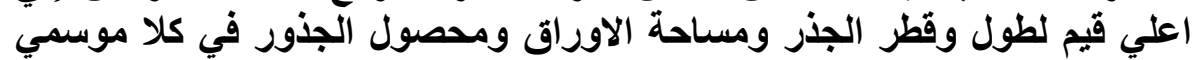

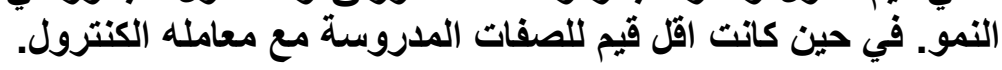

$$
\% \% \% \%
$$

